\title{
PODSTAWOWA OPIEKA ZDROWOTNA NA RZECZ DZIECI I MLODZIEŻY
}

Stan prawny na dzień 1 marca $2018 \mathrm{r}$.

\section{Streszczenie}

Niniejszy artykut stanowi analize ustawodawstwa regulujacego organizacje podstawowej opieki zdrowotnej, w szczególności podstawowej opieki zdrowotnej na rzecz dzieci i młodzieży.

W pierwszym rozdziale przedstawiono dotychczasowe rozwiazania polskiego ustawodawstwa w zakresie podstawowej opieki zdrowotnej, w szczególności przepisy ustawy z dnia 27 sierpnia 2004 r. o świadczeniach opieki zdrowotnej finansowanych ze środków publicznych.

Kolejny rozdziat skoncentrowano na regulacjach krajowych oraz międzynarodowych dotyczacych podstawowej opieki zdrowotnej na rzecz dzieci i młodzieży, w tym postanowieniach Konstytucji.

* Kamil Musial - magister prawa, aplikant adwokacki. Pracę magisterską „Podmioty lecznicze w systemie samorządu terytorialnego" obronił pod kierunkiem prof. dr hab. Ireny Lipowicz na Wydziale Prawa i Administracji Uniwersytetu Kardynała Stefana Wyszyńskiego w Warszawie w 2017 r. Działalność naukową w zakresie prawa administracyjnego skoncentrował wokół prawa ochrony zdrowia, czego efektem są publikacje oraz wystąpienia, w tym m.in. „Zasilanie energetyczne podmiotów leczniczych w sytuacjach awaryjnych - rozwiązania prawne. Wykorzystanie odnawialnych źródeł energii” (w: Tworzenie i wykorzystywanie energii ze źródeł odnawialnych (OZE). Problemy administracyjno-prawne, wyd. UKSW, Warszawa 2016), Ewolucja prawnych form dziatania administracji publicznej w Polsce na przykładzie umowy o udzielanie świadczeń zdrowotnych oraz Przedsiębiorca w ochronie zdrowia po wprowadzeniu ustawy o sieci szpitali (referaty wygłoszone w czasie Zjazdu Prawników Administratywistów w Lublinie w 2016 r. i 2017 r.). 
$W$ kolejnej części przedstawiono rozwiazania zawarte w ustawie o podstawowej opiece zdrowotnej, ze szczególnym uwzględnieniem opieki na rzecz dzieci i młodzieży. Regulacje te sa rezultatem szerokich konsultacji, w szczególności ze środowiskiem medycznym.

$W$ artykule wskazano główne przyczyny uchwalenia ustawy o podstawowej opiece zdrowotnej. Obecnie najważniejszym wyzwaniem dla stworzenia skutecznego systemu podstawowej opieki zdrowotnej na rzecz dzieci i młodzieży jest opracowanie efektywnych sposobów wypracowania projektów regulacji ustawowych w tym zakresie.

Slowa kluczowe: podstawowa opieka zdrowotna, opieka zdrowotna w szkole, lekarz POZ, pielęgniarka POZ, położna POZ, zespót POZ, dzieci i młodzież, profilaktyka w opiece zdrowotnej.

\section{Podstawowa opieka zdrowotna jako część systemu opieki zdrowotnej w Polsce. Regulacja prawna podstawowej opieki zdrowotnej zawarta w aktach ustawowych i wykonawczych przed wprowadzeniem ustawy z dnia 27 października 2017 r. o podstawowej opiece zdrowotnej ${ }^{1}$}

Tworzenie systemu opieki zdrowotnej w Polsce wymaga od ustawodawcy wszechstronnego podejścia do procesu legislacyjnego, z wykorzystaniem dorobku wielu dziedzin nauki, uwzględniającego rozwój medycyny, w szczególności w kontekście pojawiających się kontrowersyjnych zagadnień z zakresu bioetyki, biotechnologii, takich jak np. laboratoryjne sposoby wspomagania narodzin, czy śmierci ${ }^{2}$. Wsparciem w stosowaniu prawa ochrony zdrowia w zmieniającej się nieprzerwanie w związku z postępem technologicznym rzeczywistości społecznej, stanowi dorobek orzecznictwa, wykorzystującego metody wykładni systemowej i funkcjonalnej, z odwołaniem do wartości, które płyną z postanowień Konstytucji, prawa międzynarodowego i europejskiego ${ }^{3}$. Tworzenie prawa wspomóc powinny również uregulowane prawnie procedury konsultacji społecznych w ramach ustanowionych komitetów, czy rad ${ }^{4}$.

1 Ustawa z dnia 27 października 2017 r. o podstawowej opiece zdrowotnej (Dz.U. 2017, poz. 2017, ze zmianami).

2 Podstawy prawa medycznego, w: System Prawa Medycznego. Instytucje Prawa Medycznego. Tom I, red. M. Safjan, L. Bosek, C.H. Beck, Warszawa 2017, s. 14-19.

3 Tamże.

4 Tamże. 
Tak wypracowany model procesu ustawodawczego mógłby zostać z powodzeniem wykorzystany w pracach nad ustawami dotyczącymi ochrony zdrowia dzieci i młodzieży, którym szczególne prawo do ochrony zdrowia oraz dostęp do świadczeń zdrowotnych zostały im przyznane w art. 68 ust. 3 Konstytucji ${ }^{5}$. Na uwagę w tym kontekście zasługują również rozwiązania dotyczące podstawowej opieki zdrowotnej (zw. dalej POZ).

Przed wejściem w życie ustawy z dnia 27 października 2017 r. o podstawowej opiece zdrowotnej (zw. dalej ustawą o POZ), POZ definiował art. 5 pkt 27 ustawy z dnia 27 sierpnia 2004 r. o świadczeniach opieki zdrowotnej finansowanych ze środków publicznych (zw. dalej ustawą o świadczeniach opieki zdrowotnej) ${ }^{6}$, zgodnie z którym POZ obejmowała świadczenia zdrowotne profilaktyczne, diagnostyczne, lecznicze, rehabilitacyjne oraz pielęgnacyjne z zakresu medycyny ogólnej, rodzinnej, chorób wewnętrznych i pediatrii, udzielane w ramach ambulatoryjnej opieki zdrowotnej (rozumianej zgodnie z art. 5 pkt 1 ustawy o świadczeniach opieki zdrowotnej jako udzielanie przez świadczeniodawców świadczeń opieki zdrowotnej osobom niewymagającym leczenia w warunkach całodobowych lub całodziennych ${ }^{7}$ ). Obecnie przepis ten odsyła do art. 2 ustawy o $\mathrm{POZ}^{8}$, która określa również wymogi w zakresie uprawnień zawodowych pozwalających na wykonywanie świadczeń POZ dla lekarzy, pielęgniarek i położnych, dotyczące przede wszystkim wykształcenia i doświadczenia zawodowego w ramach medycyny rodzinnej lub pediatrycznej.

Mimo wprowadzenia nowej ustawy w ramach POZ nadal wykonywane są świadczenia nocnej i świątecznej opieki zdrowotnej udzielane przez świadczeniodawców poza godzinami pracy określonymi w umowach o udzielanie świadczeń podstawowej opieki zdrowotnej, w szczególności w dni wolne od pracy i w święta, w przypadku nagłego zachorowania lub nagłego pogorszenia stanu zdrowia świadczeniobiorcy, które nie jest stanem nagłym (art. 5 pkt 17a ustawy o świadczeniach opieki zdrowotnej $\left.{ }^{9}\right)$.

Nie zmieniły się również zasady udzielania świadczeń zdrowotnych w ramach POZ (w tym zakresie ustawa o POZ odsyła do przepisów ustawy o świadczeniach

\footnotetext{
5 Konstytucja Rzeczypospolitej Polskiej z dnia 2 kwietnia 1997 r. (Dz.U. 1997, nr 78 poz. 483 , ze zmianami).

6 Ustawa z dnia 27 sierpnia 2004 r. o świadczeniach opieki zdrowotnej finansowanych ze środków publicznych (Dz.U. 2004, nr 210 poz. 2135, ze zmianami).

7 Tamże.

8 Dz.U. 2017, poz. 2017, ze zmianami.

9 Dz.U. 2004, nr 210 poz. 2135, ze zmianami.
} 
opieki zdrowotnej $\left.{ }^{10}\right)$. Odbywa się ono na podstawie umowy o udzielanie świadczeń opieki zdrowotnej zawartej na czas nieoznaczony, w uproszczonym trybie, bez postępowania w sprawie konkursu ofert i rokowań (art. 159 ust. 1 pkt 1 i ust. 2 a ustawy o świadczeniach opieki zdrowotnej ${ }^{11}$ ), przez konkretnego lekarza, pielęgniarkę lub położną, zatrudnionych przez świadczeniodawców bądź realizujących indywidualną praktykę zawodową, na podstawie dokonanego przez pacjenta wyboru.

Zgodnie z uchylonym art. 28 ustawy o świadczeniach opieki zdrowotnej ${ }^{12}$ wyboru tego można było dokonać bezpłatnie 3 razy do roku, także gdy dokonanie wyboru było konieczne ze względu na zmianę miejsca zamieszkania pacjenta albo zaprzestanie udzielania świadczeń przez lekarza, pielęgniarkę lub położną (obecnie sposób wyboru regulują art. 9 oraz art. 10 ustawy o POZ ${ }^{13}$ ). Ogólne warunki umów o udzielanie świadczeń opieki zdrowotnej określa rozporządzenie Ministra Zdrowia z dnia 8 września 2015 r. w sprawie ogólnych warunków umów o udzielanie świadczeń opieki zdrowotnej ${ }^{14}$. Przepisy rozporządzenia Ministra Zdrowia z dnia 21 września 2016 r. w sprawie zakresu zadań lekarza podstawowej opieki zdrowotnej, pielęgniarki podstawowej opieki zdrowotnej i położnej podstawowej opieki zdrowotnej (zw. dalej rozporządzeniem w sprawie zakresu zadań ${ }^{15}$ kładą nacisk na współpracę i koordynację działań oraz rozpoznanie potrzeb zdrowotnych i dostosowanie do nich udzielanych świadczeń (ust. 2 załącznika nr 1 do rozporządzenia, ust. 2 załącznika nr 2 w części II A. do rozporządzenia oraz ust. 2 załącznika nr 2 w części II B. do rozporządzenia).

Zgodnie z planem finansowym Narodowego Funduszu Zdrowia (zw. dalej NFZ) na rok 2017, na udzielanie świadczeń zdrowotnych w ramach POZ została przeznaczona suma 9924407000 zł, spośród 73706789000 zł poniesionych kosztów na ogół realizowanych w opiece zdrowotnej świadczeń ${ }^{16}$.

10 Tamże.

11 Tamże.

12 Tamże.

13 Dz.U. 2017, poz. 2017, ze zmianami.

14 Rozporządzenie Ministra Zdrowia z dnia 8 września 2015 r. w sprawie ogólnych warunków umów o udzielanie świadczeń opieki zdrowotnej (Dz.U. 2015, poz. 1400, ze zmianami).

15 Rozporządzenie Ministra Zdrowia z dnia 21 września 2016 r. w sprawie zakresu zadań lekarza podstawowej opieki zdrowotnej, pielęgniarki podstawowej opieki zdrowotnej i położnej podstawowej opieki zdrowotnej (Dz.U. 2016, poz. 1567).

16 Roczny Plan Finansowy Narodowego Funduszu Zdrowia na rok 2017 (Załacznik do komunikatu Prezesa Narodowego Funduszu Zdrowia z dnia 5 sierpnia), poz. 800, s. 2. 
Kluczowe dla udzielania świadczeń zdrowotnych w ramach POZ jest ich finansowanie. Wprowadzenie ustawy o POZ nie zmieniło co do zasady regulacji w tym zakresie (art. 22 ustawy o POZ odsyła do przepisów o świadczeniach opieki zdrowotnej ${ }^{17}$ ). Zgodnie z art. 132 ust. 1 ustawy o świadczeniach opieki zdrowotnej, podstawą udzielania świadczeń opieki zdrowotnej finansowanych ze środków publicznych przez NFZ jest umowa o udzielanie świadczeń opieki zdrowotnej (zw. dalej umową o udzielanie) zawarta pomiędzy świadczeniodawcą a NFZ, z zastrzeżeniem art. 19 ust. 4. ustawy (udzielenie świadczenia zdrowotnego w stanie nagłym przez świadczeniodawcę, który nie zawarł umowy o udzielanie) $)^{18}$. Przedmiotem umowy o udzielanie jest udzielanie świadczeń zdrowotnych na rzecz pacjentów świadczeniobiorców (w rozumieniu art. 2 ust. 1 ustawy o świadczeniach opieki zdrowotnej). Umowę o udzielanie zawiera świadczeniodawca (podmiot wykonujący działalność leczniczą w rozumieniu przepisów o działalności leczniczej, osoba fizyczna niewykonująca działalności leczniczej, która uzyskała fachowe uprawnienia do udzielania świadczeń zdrowotnych i udziela ich w ramach wykonywanej działalności gospodarczej, podmiot realizujący czynności z zakresu zaopatrzenia w wyroby medyczne w rozumieniu art. 5 pkt 41 ustawy o świadczeniach opieki zdrowotnej $^{19}$ ) z NFZ ${ }^{20}$, który ,zaspokaja potrzeby ubezpieczonych, zapewniając pacjentom dostęp do świadczeń zdrowotnych z ubezpieczenia poprzez zawieranie kontraktów ze świadczeniodawcami" ${ }^{21}$. Umowa o udzielanie jest umową nazwaną, wzajemną, dwustronnie zobowiązującą, zawierającą zastrzeżenie świadczenia na rzecz osoby trzeciej ${ }^{22}$. Elementy umowy o udzielanie oraz procedurę jej zawarcia zostały określone w dziale VI ustawy o świadczeniach opieki zdrowotnej, w przypadku braku szczegółowych regulacji, stosuje się przepisy Kodeksu cywilnego (art. 155 ust. 1 ustawy o świadczeniach opieki zdrowotnej ${ }^{23}$ ).

Dla sposobu w jaki udzielane są świadczenia w ramach POZ oraz realizacji konstytucyjnego uprawnienia do otrzymania tych świadczeń, ważnym zagadnieniem jest limitowanie świadczeń. Zgodnie z art. 132 ust. 5 ustawy o świadczeniach

\footnotetext{
17 Dz.U. 2017, poz. 2017, ze zmianami.

18 Dz.U. 2004, nr 210 poz. 2135, ze zmianami.

19 Tamże.

20 B. Sygit, D. Wąsik, Prawo ochrony zdrowia, Difin, Warszawa 2016, s. 119-121.

21 T. Zimna, Zawieranie umów o udzielanie świadczeń opieki zdrowotnej, LEX Wolters Kluwer, 2007.

22 P. Pietruś, Zasady funkcjonowania podmiotów wykonujacych działalności lecznicza, w: Prowadzenie działalności leczniczej. Aspekty prawne, red. P. Bała, M. Załucki, Difin, Warszawa 2013, s. 87-89.

23 Dz.U. 2004, nr 210 poz. 2135, ze zmianami.
} 
opieki zdrowotnej wysokość łącznych zobowiązań NFZ wynikających z zawartych ze świadczeniodawcami umów nie może przekroczyć wysokości kosztów przewidzianych na ten cel w planie finansowym NFZ ${ }^{24}$. Szczególne znaczenie ma to w przypadku świadczeń POZ, w związku z tym ,instrumentem pośrednio wpływającym na kwoty zobowiązań Funduszu wobec świadczeniodawcy jest ustalanie norm zalecanej maksymalnej liczby ubezpieczonych w podstawowej opiece zdrowotnej dla świadczeniodawcy udzielającego świadczeń w tym zakresie, ponieważ z elementów przedmiotowo istotnych umowy o udzielanie świadczeń opieki zdrowotnej w rodzaju podstawowa opieka zdrowotna wyłączony został punkt określający kwotę zobowiązania Funduszu wobec świadczeniodawcy”25.

W tym kontekście należy wskazać na art. 157 ustawy o świadczeniach opieki zdrowotnej, który przy zmianie umowy o udzielanie zwalnia strony ze stosowania przepisów obowiązujących przy jej zawarciu. Powszechną praktyką jest aneksowanie umów, co tworzy skomplikowane i długotrwałe stosunki zobowiązaniowe między świadczeniodawcami a NFZ, na co wskazuje orzecznictwo ${ }^{26}$.

Rozdział poświęcono ogólnym rozważaniom dotyczącym sposobu tworzenia prawa ochrony zdrowia, udzielaniu i finansowaniu świadczeń zdrowotnych udzielanych w ramach POZ, przepisom regulującym te zagadnienia, które zostały zmienione po wejściu w życie ustawy o POZ oraz tym, których treści nie znowelizowano. $\mathrm{W}$ dalszej części zostaną omówione rozwiązania dotyczące opieki zdrowotnej udzielanej dzieciom i młodzieży oraz model POZ wprowadzony przez ustawę.

\section{Podstawowa opieka zdrowotna na rzecz dzieci i młodzieży}

Objęcie szczególną ochroną zdrowia dzieci i młodzieży stało się przedmiotem postanowień aktów prawa międzynarodowego oraz europejskiego ${ }^{27}$, a także Konstytucji (art. 68 ust. 3).

\section{Tamże.}

25 T. Zimna, Zawieranie..., dz. cyt.

26 Zob. Wyrok Sądu Najwyższego z dnia 13 maja 2005 r., sygn. akt I CK 691/04, LEX nr 603867; wyrok Sądu Najwyższego z dnia 22 stycznia 2014 r., sygn. akt III CSK 96/13, LEX nr 1455728; wyrok Wojewódzkiego Sądu Administracyjnego w Warszawie z dnia 22 stycznia 2010 r., sygn. akt VI SA/Wa 1387/09, LEX nr 600397; wyrok Wojewódzkiego Sądu Administracyjnego w Gdańsku, sygn. akt I SA/Gd 1038/17,LEX nr 2408710; wyrok Wojewódzkiego Sądu Administracyjnego w Łodzi, sygn. akt III SA/Łd 3/15, LEX nr 1793509.

27 M. Dercz, H. Izdebski, T. Rek, Dziecko - Pacjent i świadczeniobiorca. Poradnik Prawny, ABC Wolters Kluwer, Warszawa 2015, s. 17-24. 
Dlatego też, opieka zdrowotna dzieci i młodzieży jest traktowana przez ustawodawcę w szczególny sposób, w związku z tym, że dotyczy ona jednostek najsłabszych, narażonych w największym stopniu na utratę zdrowia fizycznego i psychicznego, od których w niedalekiej perspektywie będzie zależeć przyszłość państwa. Wyrazem tej szczególnej ochrony są przepisy rozporządzenia Ministra Zdrowia z dnia 28 sierpnia 2009 r. w sprawie organizacji profilaktycznej opieki zdrowotnej nad dziećmi i młodzieżąą. Zgodnie z $\S 3$ ust. 1 i ust. 2 rozporządzenia ${ }^{29}$, świadczeń z zakresu profilaktycznej opieki zdrowotnej nad dziećmi i młodzieżą udzielają lekarz POZ, pielęgniarka lub położna, która posiada wykształcenie ukierunkowane na pracę w środowisku nauczania lub odpowiedni staż pracy w ramach POZ oraz higienistka szkolna. Pielęgniarka, położna lub higienistka szkolna wykonują świadczenia w znajdującym się na terenie szkoły gabinecie profilaktyki zdrowotnej i pomocy przedlekarskiej ( 88 rozporządzenia ${ }^{30}$ ). Przepisy rozporządzenia, podobnie jak rozporządzenie w sprawie zadań w ramach POZ, przewidują współpracę między uczestnikami systemu udzielania świadczeń w środowisku szkolnym ( $\$ 10$ ust. 5 rozporządzenia $\left.{ }^{31}\right)$.

Opieka zdrowotna nad dziećmi i młodzieżą stanowi odrębny przedmiot działalności świadczeniodawców. Jednocześnie została uregulowana jako część systemu POZ. Rozporządzenie z 28 sierpnia 2009 r. wydano na podstawie art. 27 ust. 3 ustawy o świadczeniach opieki zdrowotnej ${ }^{32}$. Świadczenia na rzecz dzieci i młodzieży w środowisku szkolnym wykonuje lekarz POZ, a jeśli czyni to pielęgniarka, położna lub higienistka szkolna, to po zakończeniu nauki, dokumentacja medyczna ucznia trafia do lekarza POZ, który sprawuje nad nim opiekę na podstawie dokonanego wyboru.

Zgodnie z informacjami zawartymi na stronie internetowej NFZ, profilaktyczna opieka zdrowotna w środowisku szkolnym obejmuje badania okresowe wykonywane regularnie w odstępach średnio dwuletnich do ukończenia przez ucznia 19. roku życia, ponadto pielęgniarka szkolna współpracuje z lekarzem POZ w zakresie opieki zdrowotnej nad uczniami przewlekle chorymi lub niepełnosprawnymi pomocy w sytuacjach nagłego zagrożenia zdrowia. Świadczenia opieki zdrowotnej

28 Rozporządzenie Ministra Zdrowia z dnia 28 sierpnia 2009 r. w sprawie organizacji profilaktycznej opieki zdrowotnej nad dziećmi i młodzieżą (Dz.U. 2009, nr 139 poz. 1133).

29 Dz.U. 2009, nr 139 poz. 1133.

30 Tamże.

31 Tamże.

32 Dz.U. 2004, nr 210 poz. 2135, ze zmianami. 
w środowisku szkolnym finansowane są na podstawie listy uczniów szkół, w których realizuje swoje zadania świadczeniodawca ${ }^{33}$.

Z wejściem w życie ustawy o POZ zmieniono regulację zakresu świadczeń udzielanych na rzecz dzieci i młodzieży w środowisku pozaszkolnym. Dotychczas zgodnie z przepisami ustawy o świadczeniach opieki zdrowotnej, obejmowały one: wczesną, wielospecjalistyczną i kompleksową opiekę nad dzieckiem zagrożonym niepełnosprawnością lub niepełnosprawnym, promocję zdrowia i profilaktykę, w tym profilaktykę stomatologiczną obejmującą dzieci i młodzież do ukończenia 19. roku życia, wykonywanie szczepień ochronnych (art. 27 ust. 2, 4, 7 ustawy o świadczeniach opieki zdrowotnej sprzed nowelizacji ${ }^{34}$, obecnie art. 27 ust. 3 ustawy zawiera delegację ustawową dla Ministra Zdrowia do wydania rozporządzenia w sprawie organizacji profilaktycznej opieki zdrowotnej dla dzieci i młodzieży ${ }^{35}$ ).

Dzieci i młodzież zgłasza, na dotychczasowych zasadach, do ubezpieczenia pracujący rodzic, do 18. lub 26. roku życia, w przypadku kontynuowania nauki i niepodjęcia w tym czasie przez dziecko pracy (art. 67 ust. 3 i 3 a ustawy o świadczeniach opieki zdrowotnej $\left.{ }^{36}\right)$.

Ukształtowany w ten sposób system świadczeń zdrowotnych udzielanych na rzecz dzieci i młodzieży stanowi integralną część POZ, która została uregulowana na poziomie podstawowym w ustawie o świadczeniach opieki zdrowotnej, a w sposób szczegółowy w ustawie o POZ.

W tym kontekście warte uwagi są projekty uwzględnienia konieczności zapewnienia tej szczególnej ochrony poprzez np. zmiany sposobu finansowania świadczeń zdrowotnych na rzecz dzieci i młodzieży ${ }^{37}$, czy też skoordynowania opieki zdrowotnej z systemem zabezpieczenia społecznego $0^{38}$.

\section{Podstawowa opieka zdrowotna po wejściu w życie ustawy o POZ}

Dotychczas obowiązujące regulacje określały zasadnicze dla funkcjonowania POZ wymogi, dotyczące: systemu finansowania świadczeń, ich realizacji, poziomu

\footnotetext{
33 Strona internetowa NFZ: www.nfz.gov.pl/dla-pacjenta/informacje-o-swiadczeniach/ podstawowa-opieka-zdrowotna [dostęp: 15.03.2018 r.].

34 Dz.U. 2004, nr 210 poz. 2135, ze zmianami.

35 Tamże.

36 Tamże.

37 M. Dercz, H. Izdebski, T. Rek, Dziecko - Pacjent..., dz. cyt., s. 34-38.

38 E. Respond, Prawne aspekty ochrony zdrowia dzieci w Polsce, „Roczniki Nauk Prawnych" 2014, tom XXIV, nr 3, KUL, s. 54-56.
} 
dostępności, koordynacji działań świadczeniodawców, kwalifikacji kadry medycznej. W praktyce funkcjonowania POZ ujawniły się nieprawidłowości, związane ze sposobem finansowania świadczeń (czemu zaradzić w dużym stopniu ma w intencji ustawodawcy uchwalona ustawa o POZ), co w konsekwencji przyczyniło się do strukturalnych problemów w zakresie realizacji świadczeń zdrowotnych.

Wyniki kontroli Najwyższej Izby Kontroli z dnia 27 października 2015 r. Funkcjonowanie podstawowej $i$ ambulatoryjnej opieki specjalistycznej ${ }^{39}$, wskazują na szereg nieprawidłowości przy wykonywaniu świadczeń w zakresie POZ, w tym w szczególności dotyczących systematycznego prowadzenia dokumentacji medycznej (co nie sprzyja zaspokajaniu zdrowotnych potrzeb ludności), struktury zatrudnienia (w latach 2012-2014 w związku z niepełnoetatowym zatrudnieniem tylko połowa świadczeń była wykonywana przez lekarza z wyboru, lekarze rodzinni udzielili w tym okresie 30 procent świadczeń), prawdziwości danych zgłoszonych przez podmioty lecznicze do odpowiedniego rejestru (stwierdzone u 6 z 45 kontrolowanych świadczeniodawców), działań Ministra Zdrowia w zakresie planowania i kształtowania polityki zdrowotnej kształtującej sposób wykonywania świadczeń w zakresie POZ. Jak stwierdzono: „Zakres prowadzonych przez Ministra Zdrowia analiz i ocen potrzeb zdrowotnych w zakresie opieki ambulatoryjnej, podstawowej i specjalistycznej, w okresie objętym kontrolą, był ograniczony. Nie dokonywano systematycznej oceny dostępności świadczeń POZ i AOS. $\mathrm{W}$ działaniach na rzecz rozwiązania zidentyfikowanych, m.in. przez konsultantów krajowych, systemowych problemów ochrony zdrowia nie korzystano z potencjału naukowego i badawczego nadzorowanych szkół wyższych oraz instytutów badawczych. W ocenie NIK, zaniechanie korzystania z tego zaplecza eksperckiego może mieć negatywny wpływ na jakość strategicznego planowania dotyczącego funkcjonowania systemu ochrony zdrowia. (...) Najwyższa Izba Kontroli uznała również za niewystarczające działania na rzecz edukacji prozdrowotnej i profilaktyki, kształtującej świadomość osobistej odpowiedzialności obywateli za swoje zdrowie już od najmłodszych lat" ${ }^{\prime 40}$.

Wskazane nieprawidłowości stały się przyczyną do wyjścia przez Ministra Zdrowia $\mathrm{z}$ inicjatywą zmian legislacyjnych w zakresie POZ. W uzasadnieniu do projektu ustawy o POZ wskazano, iż intencją projektodawców było przede wszystkim: „Zapewnienie kompleksowości i wysokiej jakości POZ oraz stworzenie warunków umożliwiających finansowe motywowanie świadczeniodawców udzielających świadczeń opieki zdrowotnej finansowanych ze środków publicznych do

39 Wyniki kontroli Najwyższej Izby Kontroli z dnia 27 października 2015 r.: Funkcjonowanie podstawowej i ambulatoryjnej opieki specjalistycznej, Warszawa 2015.

40 Tamże, s. 8-9. 
podnoszenia poziomu jakości udzielanych świadczeń poprzez rozwój zawodowy i współpracę zespołu. Projektowana ustawa definiuje rolę i miejsce POZ w systemie ochrony zdrowia, a w konsekwencji umożliwi poprawę jej organizacji i funkcjonowania, jak również stworzy warunki do zwiększenia jej efektywności. W szczególności istotna jest poprawa koordynacji opieki i pracy zespołowej w zakresie odrębnych kompetencji lekarza POZ, pielęgniarki POZ i położnej POZ, w tym również w przypadkach faktycznego oddzielenia strukturalnego, ze szczególnym uwzględnieniem poprawy organizacji zarządzania opieką nad pacjentem"41.

Ustawa o POZ uchwalona w dniu 27 października 2017 r., została podzielona na sześć rozdziałów: Przepisy ogólne; Organizacja podstawowej opieki zdrowotnej; Finansowanie podstawowej opieki zdrowotnej; Jakość świadczeń z zakresu podstawowej opieki zdrowotnej; Przepisy zmieniające; Przepisy przejściowe, dostosowujące i końcowe ${ }^{42}$. Zgodnie $\mathrm{z}$ art. 1 ustawa określa cele i organizację podstawowej opieki zdrowotnej oraz zasady zapewnienia odpowiedniej jakości świadczeń opieki zdrowotnej z zakresu podstawowej opieki zdrowotnej ${ }^{43}$. Art. 2 definiuje pojęcie POZ, która obecnie stanowi miejsce pierwszego kontaktu świadczeniobiorcy, w rozumieniu przepisów ustawy z dnia 27 sierpnia 2004 r. o świadczeniach opieki zdrowotnej, z systemem ochrony zdrowia, z wyłączeniem sytuacji, w których świadczeniobiorca znajduje się w stanie nagłego zagrożenia zdrowotnego, o którym mowa w art. 3 pkt 8 ustawy z dnia 8 września 2006 r. o Państwowym Ratownictwie Medycznym $^{44}$, lub udzielane są mu świadczenia, o których mowa w art. 57 ust. 2 ustawy z dnia 27 sierpnia 2004 r. o świadczeniach opieki zdrowotnej (świadczenia specjalistyczne, które nie wymagają skierowania lekarskiego), w ramach którego jest zapewniony dostęp do profilaktycznych, diagnostycznych, leczniczych, pielęgnacyjnych oraz rehabilitacyjnych świadczeń opieki zdrowotnej, finansowanych ze środków publicznych ${ }^{45}$. Przytoczona definicja wskazuje na intencje ustawodawcy co do zmiany sposobu funkcjonowania POZ. Ma być ona miejscem pierwszego kontaktu dla pacjenta, w którym zostanie mu zapewniony dostęp do szeregu świadczeń zdrowotnych. Co istotne, obecna regulacja kładzie nacisk na realizację obowiązków przez świadczeniodawców, a wykonywane świadczenia nie zostały ograniczone, jak poprzednio, do ambulatoryjnej opieki zdrowotnej.

${ }^{41}$ Strona internetowa Rządowego Centrum Legislacji: www.legislacja.rcl.gov.pl/projekt/12293658 [dostęp: 15.03.2018 r.].

42 Dz.U. 2017, poz. 2017, ze zmianami.

43 Tamże.

44 Ustawa z dnia 8 września 2006 r. o Państwowym Ratownictwie Medycznym (Dz.U. 2006, nr 191 poz. 1410, ze zmianami).

45 Dz.U. 2017, poz. 2017, ze zmianami. 
W art. 3 ustawy o POZ określono cele POZ, do których należy:

1. zapewnienie opieki zdrowotnej nad świadczeniobiorcą i jego rodziną;

2. koordynacja opieki zdrowotnej nad świadczeniobiorcą w systemie ochrony zdrowia;

3. ocena potrzeb oraz ustalenie priorytetów zdrowotnych populacji objętej opieką oraz wdrażanie działań profilaktycznych;

4. rozpoznawanie, eliminowanie lub ograniczanie zagrożeń i problemów zdrowia fizycznego i psychicznego;

5. zapewnienie profilaktycznej opieki zdrowotnej oraz promocji zdrowia dostosowanych do potrzeb różnych grup społeczeństwa;

6. zapewnienie edukacji świadczeniobiorcy w zakresie odpowiedzialności za własne zdrowie i kształtowanie świadomości prozdrowotnej ${ }^{46}$.

Jak można przeczytać w uzasadnieniu do projektu ustawy, ustawodawca przyjął sobie za cel wprowadzenie modelu poprawiającego koordynację działań i współpracę między udzielającymi świadczeń zdrowotnych pracownikom ochrony zdrowia oraz świadczeniodawcami. Materia ta została uregulowana w art. 4 i 5 ustawy o POZ. Koordynacja opieki zdrowotnej nad pacjentem w systemie ochrony zdrowia polega na zintegrowaniu udzielania świadczeń opieki zdrowotnej, obejmujących wszystkie etapy i elementy procesu ich realizacji, z wykorzystaniem systemów teleinformatycznych, środków komunikacji elektronicznej lub publicznie dostępnych usług telekomunikacyjnych, ze szczególnym uwzględnieniem jakości i efektywności udzielanych świadczeń (art. 4 ustawy o POZ ${ }^{47}$ ). Koordynację, we współpracy z pielęgniarką POZ i położną POZ, zapewnia lekarz POZ, który inicjuje lub kontynuuje postępowanie diagnostyczno-lecznicze podejmowane w odniesieniu do świadczeniobiorcy przez innego świadczeniodawcę, w ramach swoich kompetencji zawodowych, zgodnie z aktualną wiedzą medyczną (art. 5 ust. 1 i 2 ustawy o $\mathrm{POZ}^{48}$ ). Pielęgniarka POZ i położna POZ, w ramach współpracy z lekarzem POZ, rozpoznają warunki i potrzeby zdrowotne u świadczeniobiorcy oraz problemy pielęgnacyjne, planują i sprawują kompleksową opiekę pielęgniarską, a także kontynuują postępowanie terapeutyczne zlecone przez innego świadczeniodawcę, $\mathrm{w}$ ramach swoich kompetencji zawodowych, zgodnie $\mathrm{z}$ aktualną wiedzą medyczną (art. 5 ust. 3 ustawy o $\mathrm{POZ}^{49}$ ). Art. 6-9 ustawy o POZ regulują kwalifikacje oraz obowiązki lekarza POZ, pielęgniarki POZ oraz położnej POZ ${ }^{50}$. Należy zauważyć,

$\begin{array}{ll}46 & \text { Tamże. } \\ 47 & \text { Tamże. } \\ 48 & \text { Tamże. } \\ 49 & \text { Tamże. } \\ 50 & \text { Tamże. }\end{array}$ 
iż mimo wejścia w życie ustawy o POZ, wciąż obowiązują przepisy rozporządzenia w sprawie zakresu zadań. W art. 9 i 10 ustawy o POZ uregulowano zasady wyboru lekarza POZ, pielęgniarki POZ oraz położnej POZ przez pacjenta, ograniczając możliwość bezpłatnego wyboru do dwóch razy w ciągu roku (każdy następny wiązać się będzie z opłatą w wysokości $80 \mathrm{zl})^{51}$.

W rozdziale 2 ustawy uregulowano sposób organizacji POZ, której zadania realizowane są w ramach zespołu POZ, złożonego z lekarza POZ, pielęgniarki POZ oraz położnej POZ. Ustawodawca wskazał przy tym zadania członków zespołu POZ (art. 12 ustawy $^{52}$ ) na obowiązki świadczeniodawcy w zakresie udzielania świadczeń w ramach POZ, szczególnie w zakresie koordynacji opieki zdrowotnej, obejmujące: profilaktyczną opiekę zdrowotną dostosowaną do wieku i płci świadczeniobiorcy oraz zidentyfikowanych problemów zdrowotnych świadczeniobiorcy i populacji objętej opieką; badania diagnostyczne i konsultacje specjalistyczne, zgodnie z indywidualnym planem diagnostyki, leczenia i opieki; wyznaczanie osoby, do której zadań należy organizacja procesu udzielania świadczeń zdrowotnych, w tym udzielanie informacji o tym procesie oraz zapewnienie współpracy między osobami udzielającymi świadczeń zdrowotnych (art. 14 ustawy ${ }^{53}$ ). W art. 16 ustawy określone zostały zasady współpracy w ramach POZ, polegającej na stałej wymianie informacji o świadczeniobiorcy oraz podejmowaniu wspólnych działań przez członków zespołu POZ, w zakresie niezbędnym do zachowania zdrowia, profilaktyki, rozpoznawania i leczenia chorób, pielęgnowania oraz rehabilitacji świadczeniobiorcy (art. 16 ust. 1 ustawy ${ }^{54}$ ). W kolejnych artykułach uregulowano zasady współpracy zespołu POZ z pielęgniarką środowiska nauczania i wychowania lub higienistką szkolną oraz innymi podmiotami.

W toku prac nad ustawą wątpliwości wzbudził projekt udzielania świadczeń w ramach opieki zintegrowanej i budżetu powierzonego. Jednak, jak zapisano w art. 22 ustawy o POZ, finansowanie świadczeń odbywać się będzie na zasadach określonych w ustawie o świadczeniach opieki zdrowotnej. W praktyce, koncepcję opieki zintegrowanej w pierwotnym kształcie zarzucono, a zmiany w tym zakresie wejdą w życie dopiero z dniem 1 października 2020 r., wprowadzając konieczność uwzględnienia $\mathrm{w}$ ramach budżetu przeznaczonego na świadczeniach $\mathrm{w}$ ramach POZ, z wyjątkiem nocnej i świątecznej opieki zdrowotnej, dodatkowych środków w ramach budżetu powierzonego oraz na opłatę zadaniową i dodatek motywacyjny

\footnotetext{
51 Tamże.

52 Tamże.

53 Tamże.

54 Tamże.
} 
(art. 29 pkt $11 \mathrm{w}$ zw. z art. 38 pkt 3 ustawy o POZ ${ }^{55}$ ). W związku z tym, rozważania poczynione w pierwszym rozdziale dotyczące sposobu finansowania świadczeń zdrowotnych, także w ramach POZ, pozostają aktualne.

Warto zwrócić uwagę na sposób wprowadzenia zmian w organizacji POZ. Zdecydowano się na uchwalenie odrębnej ustawy, obok ustawy o świadczeniach opieki zdrowotnej, która do tej pory regulowała podstawowe zagadnienia związane z POZ. Jak thumaczą projektodawcy, związane jest to z rolą jaką POZ odgrywa w opiece zdrowotnej i jej znaczeniem dla realizacji potrzeb zdrowotnych obywateli. Uzasadnienie to jest słuszne. Nie można jednak odwrócić uwagi od niekonsekwencji ustawodawcy przy wprowadzaniu zmian legislacyjnych w ochronie zdrowia. Ustawa o POZ ma regulować fundamentalne zagadnienia w tej dziedzinie. Należy jednak przypomnieć, że jak wskazano wyżej, rozwiązania dotyczące kwestii objętych materią ustawy o POZ, zostały już uregulowane w istniejących aktach prawnych, przede wszystkim w ustawie o świadczeniach opieki zdrowotnej, jak również w aktach wykonawczych dotyczących m.in. organizacji funkcjonowania świadczeniodawców i wymogów stawianych przed kadrą medyczną udzielającą świadczeń. Trzeba postawić pytanie, czy zmiany polegające na skonsolidowaniu rozproszonych regulacji $\mathrm{w}$ jeden akt prawny, powinny rodzić chaos legislacyjny, bo jak zaznaczono również w uzasadnieniu do projektu ustawy, konieczna będzie zmiana lub uchylenie przepisów innych ustaw i rozporządzeń. Przepisy zmieniające, przejściowe, dostosowujące i końcowe zostały zredagowane od art. 25 do art. 38 ustawy o POZ, stanowiąc niemal połowę jej treści. Zmiany dotkną przepisy ustawy z dnia 21 listopada 1967 r. o powszechnym obowiązku obrony Rzeczypospolitej Polskiej $^{56}$, ustawy z dnia 12 października 1990 r. o Straży Granicznej ${ }^{57}$, ustawy z dnia 6 czerwca 1997 r. - Kodeks karny wykonawczy ${ }^{58}$, ustawy z dnia 27 lipca 2001 r. - Prawo o ustroju sądów powszechnych ${ }^{59}$, ustawy z dnia 5 grudnia 2008 r. o zapobieganiu oraz zwalczaniu zakażeń i chorób zakaźnych u ludzi ${ }^{60}$, ustawy

\footnotetext{
55 Tamże.

56 Ustawa z dnia 21 listopada 1967 r. o powszechnym obowiązku obrony Rzeczypospolitej Polskiej (Dz.U. 1967, nr 44 poz. 220).

57 Ustawa z dnia 12 października 1990 r. o Straży Granicznej (Dz.U. 1990, nr 78 poz. 462, ze zmianami).

58 Ustawa z dnia 6 czerwca 1997 r. - Kodeks karny wykonawczy (Dz.U. 1997, nr 90 poz. 557, ze zmianami).

59 Ustawa z dnia 27 lipca 2001 r. Prawo o ustroju sądów powszechnych (Dz.U. 2001, nr 98 poz. 1070, ze zmianami).

60 Ustawa z dnia 5 grudnia 2008 r. o zapobieganiu oraz zwalczaniu zakażeń i chorób zakaźnych u ludzi (Dz.U. 2008, nr 234 poz. 1570, ze zmianami).
} 
z dnia 9 czerwca 2011 r. o wspieraniu rodziny i systemie pieczy zastępczej ${ }^{61}$, ustawy z dnia 15 kwietnia 2011 r. o działalności leczniczej ${ }^{62}$ oraz przede wszystkim ustawy o świadczeniach opieki zdrowotnej, której przepisy uzupełniają często treść ustawy o POZ, jak np. w przypadku finansowania świadczeń opieki zdrowotnej, definicji świadczeniobiorcy i samej POZ.

W tym miejscu należy przypomnieć, w jaki sposób uchwalono zmiany wprowadzające do ochrony zdrowia system zabezpieczenia szpitalnego. Ustawa nowelizująca ustawę o świadczeniach opieki zdrowotnej, zwana ,ustawą o sieci szpitali”, wprowadziła $\mathrm{w}$ istocie, nieznaną do tej pory polskiemu systemowi prawnemu konstrukcję, która odwróciła zasady udzielania świadczeń zdrowotnych. Inaczej niż w przypadku ustawy o POZ, mieliśmy wtedy do czynienia z instytucją, która wymagała odrębnej regulacji, a w prowadzona aktem nowelizującym ustawę o świadczeniach opieki zdrowotnej, zrodziła jedynie niejasności w przeprowadzonych zmianach. Niezależnie od metody regulacji wykorzystanej przez ustawodawcę, należy uważnie przyjrzeć się wprowadzonym zmianom, oczekując spodziewanych przez projektodawców efektów, które byłyby z pewnością korzystne dla pacjentów.

Przed wejściem w życie ustawy o POZ, w czasie konsultacji społecznych nad projektem ustawy, szereg środowisk, w szczególności przedstawicieli zawodów medycznych, zgłosiło swoje zastrzeżenia co do proponowanych rozwiązań. Naczelna Rada Lekarska w swoim stanowisku nr 1/17/VI z dnia 13 stycznia 2017 r. wystosowała propozycje dotyczące: utrzymania uprawnień dla lekarzy udzielających świadczeniach w ramach POZ na dotychczasowych zasadach, nie ograniczając grupy uprawnionych do lekarzy rodzinnych (ochrona praw nabytych, postulat uwzględniony w toku prac legislacyjnych); w prowadzenia wymogu wykonywania świadczeń przez zespół POZ u tego samego świadczeniodawcy, co miałoby służyć zapewnieniu ciągłości i kompleksowości świadczeń; możliwości zawierania umów na badania diagnostyczne i specjalistyczne przez lekarza POZ również z lekarzami, którzy nie podpisali umów o udzielanie świadczeń zdrowotnych z NFZ, co pomogłoby realnie zwiększyć dostęp do świadczeńn ${ }^{63}$.

Z kolei Ogólnopolski Związek Zawodowy Lekarzy w swoim stanowisku z dnia 20 stycznia 2017 r. podniósł następujące uwagi: ustawa w swojej istocie sprowadza dotychczasowe regulacje w obręb jednego aktu prawnego, jest więc powtórzeniem

61 Ustawa z dnia 9 czerwca 2011 r. o wspieraniu rodziny i systemie pieczy zastępczej (Dz.U. 2011, nr 149 poz. 887, ze zmianami).

62 Ustawa z dnia 15 kwietnia 2011 r. o działalności leczniczej (Dz.U. 2011, nr 112 poz. 654, ze zmianami).

63 Strona internetowa Naczelnej Izby Lekarskiej: www.nil.org.pl/__data/assets/pdf_ file/0009/110421/rs001-17-VII.pdf [dostęp: 15.03.2018 r.]. 
obowiązującego prawa; najistotniejsza zmiana, wprowadzająca opiekę zintegrowaną oraz budżet powierzony POZ i AOS może spowodować nadmierne ograniczenie porad specjalistycznych, w związku z czym świadczenia nie zostaną udzielone naprawdę potrzebującym pacjentom, o czym będzie teraz decydował lekarz POZ (Związek zgadza się z kierunkiem zmian, które mają na celu ograniczenie wizyt u lekarzy AOS, w sytuacji, gdy wystarczające jest udzielenie świadczeń przez lekarza POZ); nowe zasady udzielania AOS spowodują wzrost obowiązków administracyjnych dla lekarzy POZ w ramach czasu pracy pozostającego na tym samym poziomie; pozostawienie pakietu onkologicznego powoduje uprzywilejowania grup pacjentów w dostępie do świadczeń AOS, nie prowadzi do funkcjonowania bezkolejkowego systemu udzielania świadczeń ${ }^{64}$.

Uczestnicy XVII Kongresu Medycyny Rodzinnej, który odbył się w Krakowie w dniach 25-28 maja 2017 r., wyrazili nadzieję, na jak najszybsze uchwalenie ustawy o POZ, dając jednocześnie do zrozumienia, że lekarze rodzinni są gotowi na prowadzenie koordynacji sposobu udzielania świadczeń w ramach POZ i AOS, z satysfakcją przyjmując rozwiązania, które zwiększają ich rolę w wykonywaniu świadczeń $\mathrm{POZ}^{65}$.

Istotna rola w znowelizowanym modelu udzielania świadczeń POZ przypadnie pielęgniarkom i położnym. Jak zauważyła Zofia Małas, Prezes Naczelnej Izby Pielęgniarek i Położnych: „Jedna trzecia pielęgniarek w Polsce, pracuje na kontraktach lub prowadzi własne (praktyki). Dlatego cieszymy się, że w projekcie ustawy o POZ pojawił się zapis, który wyraźnie wskazuje, że pielęgniarki i położne mogą stanowić odrębne podmioty" ${ }^{\prime 6}$. Nie może dziwić zainteresowanie środowiska, formami zatrudnienia pozwalającymi na uzyskanie satysfakcjonującego wynagrodzenia za pracę obarczoną coraz większa ilością obowiązków prawnych i administracyjnych, których zakres zwiększy się w związku z uchwaleniem ustawy o POZ.

Postulaty przedstawicieli zawodów medycznych skoncentrowały się w pierwszym rzędzie na roli, jaką będą odgrywać po wprowadzonych zmianach legislacyjnych w ramach POZ. Ich stanowisko należało wziąć poważnie pod uwagę,

64 Strona internetowa Ogólnopolskiego Związku Zawodowego Lekarzy: www.ozzl. org.pl [dostęp: 15.03.2018 r.].

65 Strona internetowa www.rynekzdrowia.pl/Uslugi-medyczne/Lekarze-rodzinnijestesmy-gotowi-przejac-koordynacje-opieki-nad-pacjentem,173198,8.html [dostęp: 15.03.2018 r.].

66 Strona internetowa www.rynekzdrowia.pl/Polityka-zdrowotna/Pielegniarki-chcautrzymac-samodzielnosc-Projektowany-zapis-ja-potwierdza,170611,14.html [dostęp: 15.03.2018 r.]. 
w związku z tym, że to na nich spocznie ciężar wprowadzenia uchwalonych przez ustawodawcę rozwiązań w życie, w celu faktycznego wykonywania świadczeń w znowelizowanym modelu. Środowisko medyczne obawiało się przede wszystkim o funkcjonowanie modelu opieki zintegrowanej i budżetu powierzonego, stawiając pytanie, czy za potrzebą wykonywania świadczeń na określonym poziomie i w określonej ilości, pójdą środki finansowe. W związku z tego rodzaju wątpliwościami w uchwalonym tekście ustawy nie znalazły się przepisy dotyczące opieki zintegrowanej, a regulacje wprowadzające konieczność wydzielenia budżetu powierzonego wejdą w życie dopiero od 1 października $2020 \mathrm{r}$.

Rzecznik Praw Dziecka wyraził natomiast obawę o rolę pediatrów w systemie, którzy będą mogli wykonywać świadczenia w ramach POZ tylko do 2025 r., zdaniem Rzecznika wpłynie to na jakość i dostępność świadczeń dla dzieci67.

Jak już wspomniano w pierwszym rozdziale Ustawa o POZ nie wprowadziła szczególnych rozwiązań dotyczących opieki zdrowotnej dzieci i młodzieży. Znowelizowany art. 27 ustawy o świadczeniach opieki zdrowotnej, który wcześniej wymieniał przykładowy katalog świadczeń udzielanych na rzecz dzieci i młodzieży, zawiera obecnie jedynie delegację dla Ministra Zdrowia do wydania rozporządzenia regulującego zasady udzielania świadczeń w zakresie profilaktycznej opieki zdrowotnej dzieci i młodzieży. Najistotniejszą kwestią, którą zajął się ustawodawca wprowadzając ustawę o POZ, jest prawo do wykonywania świadczeń w ramach POZ przez lekarza pediatrę. W obecnym kształcie ustawa pozwala na udzielanie świadczeń lekarzowi pediatrze do ukończenia przez pacjenta 18 roku życia (art. 6 ust. 3).

Troska o stan zdrowia dzieci i młodzieży, co oczywiste, jest bardzo potrzebna i słuszna. W tym kontekście na uwagę zasługuje wystąpienie Wiceminister Zdrowia Józefy Szczurek-Żelazko, która w Sejmie w dniu 7 lipca 2017 r. przedstawiła w imieniu Ministra Zdrowia założenia dotyczące ustawy o zdrowiu dzieci i młodzieży, wskazując na konieczność zwiększenia nacisku na profilaktykę badań w środowisku szkolnym i zwiększenie efektywności finansowania i udzielania świadczeń przez pielęgniarkę szkolną, która koordynowałaby opiekę nad młodymi pacjentami z lekarzami rodzinnymi i pielęgniarkami środowiskowymi. Projekt, zgodnie z informacją Wiceminister, jest koordynowany z Ministerstwem Edukacji Narodowej i środowiskiem szkolnym ${ }^{68}$. Dopiero uchwalenie tej ustawy będzie wyrazem zainteresowania ustawodawcy stanem zdrowia dzieci i młodzieży w Polsce.

67 Strona internetowa www.rynekzdrowia.pl/Polityka-zdrowotna/RPD-prawa-malychpacjentow-nie-moga-podlegac-zimnej-kalkulacji,170765,14.html [dostęp: 15.03.2018 r.].

68 Strona internetowa pulsmedycyny.pl/4668917,48625,ustawa-o-zdrowiu-dzieci-i-mlodziezy-na-ukonczeniu [dostęp: 15.03.2018 r.]. 


\section{Podsumowanie}

Nie ulega wątpliwości, że problem modelu udzielania świadczeń zdrowotnych w ramach POZ jest podstawową kwestią dla funkcjonowania systemu opieki zdrowotnej w Polsce, trudną do uregulowania, o czym świadczą najlepiej opinie przedstawicieli zawodów medycznych i ekspertów zaangażowanych w procedurę konsultacji nad projektem uchwalonej ustawy o POZ.

Ustawodawca skoncentrował się przede wszystkim na zmianie sposobu udzielania świadczeń POZ poprzez utworzenie zespołu POZ złożonego z lekarza, pielęgniarki i położnej, który ma zapewnić koordynację opieki nad pacjentem. W związku z tym, zdecydowano się na znowelizowanie sposobu finansowania świadczeń POZ poprzez wprowadzenie konstrukcji budżetu powierzonego oraz opłaty zadaniowej i dodatku motywacyjnego. W intencji ustawodawcy ma to stanowić swojego rodzaju impuls do realizacji zadań przez członków zespołów POZ.

Efektywność udzielania świadczeń zdrowotnych i optymalizacja ich finansowania nie może przysłonić troski o zdrowie dzieci i młodzieży, co słusznie zaznaczył Rzecznik Praw Dziecka. W tym kontekście ważne są prace nad projektem odrębnej ustawy o zdrowiu dzieci i młodzieży, w sytuacji, gdy podstawowe rozwiązania $\mathrm{w}$ tej dziedzinie, uregulowane były dotychczas na poziomie aktów wykonawczych.

Warto byłoby rozpocząc pracę nad rozwiązaniami, które w realny sposób wsparłyby proces tworzenia i stosowania prawa w zakresie podstawowej opieki zdrowotnej, w szczególności tej udzielanej dzieciom i młodzieży, realizującej ich konstytucyjne uprawnienia.

Należałoby się zastanowić nad możliwością utworzenia w drodze ustawy grup konsultacyjnych, stanowiących prawdziwą platformę wymiany poglądów oraz inicjatyw dla osób posiadających doświadczenie i wiedzę w dziedzinie ochrony zdrowia, z uwzględnieniem świadczeń realizowanych w ramach POZ oraz szczególnej opieki poświęconej zdrowiu dzieci i młodzieży. Zapisane w ustawach rozwiązania, mogłyby realizować placówki naukowo-badawcze, na czele z uczelniami medycznymi, których potencjał techniczny, organizacyjny oraz intelektualny, jak wskazał raport NIK, jest wykorzystywany w niewielkim stopniu.

\section{Bibliografia}

Dercz M., Izdebski H., Rek T., Dziecko - Pacjent i świadczeniobiorca. Poradnik Prawny, ABC Wolters Kluwer, Warszawa 2015.

Funkcjonowanie podstawowej i ambulatoryjnej opieki specjalistycznej, Warszawa 2015. 
Pietruś P., Zasady funkcjonowania podmiotów wykonujących działalności lecznicza, w: Prowadzenie działalności leczniczej. Aspekty prawnej, red. Bała P., Załucki M., Difin, Warszawa 2013.

Podstawy prawa medycznego, w: System Prawa Medycznego. Instytucje Prawa Medycznego, red. M. Safjan, L. Bosek, tom I, C.H. Beck, Warszawa 2017.

Respond E., Prawne aspekty ochrony zdrowia dzieci w Polsce, „Roczniki Nauk Prawnych", tom XXIV, nr 3, KUL, Lublin 2014.

Roczny Plan Finansowy Narodowego Funduszu Zdrowia na rok 2017 (Załącznik do komunikatu Prezesa Narodowego Funduszu Zdrowia z dnia 5 sierpnia), poz. 800 .

Rozporządzenie Ministra Zdrowia z dnia 8 września 2015 r. w sprawie ogólnych warunków umów o udzielanie świadczeń opieki zdrowotnej (Dz.U. 2015, poz. 1400, ze zmianami).

Rozporządzenie Ministra Zdrowia z dnia 21 września 2016 r. w sprawie zakresu zadań lekarza podstawowej opieki zdrowotnej, pielęgniarki podstawowej opieki zdrowotnej i położnej podstawowej opieki zdrowotnej (Dz.U. 2016, poz. 1567).

Rozporządzenie Ministra Zdrowia z dnia 28 sierpnia 2009 r. w sprawie organizacji profilaktycznej opieki zdrowotnej nad dziećmi i młodzieżą (Dz.U. 2009, nr 139 poz. 1133).

Strona internetowa NFZ: www.nfz.gov.pl/dla-pacjenta/informacje-oswiadczeniach/ podstawowa-opieka-zdrowotna.

Strona internetowa Rządowego Centrum Legislacji: www.legislacja.rcl.gov.pl/ projekt/12293658.

Strona internetowa Naczelnej Izby Lekarskiej: www.nil.org.pl/__data/assets/ pdf_file/0009/110421/rs001-17-VII.pdf.

Strona internetowa Ogólnopolskiego Związku Zawodowego Lekarzy: www.ozzl. org.pl.

Strona internetowa www.rynekzdrowia.pl/Uslugi-medyczne/Lekarze-rodzinnijestesmy-gotowi-przejac-koordynacje-opieki-nad-pacjentem,173198,8.html.

Strona internetowa www.rynekzdrowia.pl/Polityka-zdrowotna/Pielegniarki-chcautrzymac-samodzielnosc-Projektowany-zapis-ja-potwierdza,170611,14.html.

Strona internetowa www.rynekzdrowia.pl/Polityka-zdrowotna/RPD-prawamalych-pacjentow-nie-moga-podlegac-zimnej-kalkulacji,170765,14.html.

Strona internetowa pulsmedycyny.pl/4668917,48625, ustawa-o-zdrowiu-dzieci-i-mlodziezy-na-ukonczeniu.

Sygit B., Wąsik D., Prawo ochrony zdrowia, Difin, Warszawa 2016.

Ustawa z dnia 27 sierpnia 2004 r. o świadczeniach opieki zdrowotnej finansowanych ze środków publicznych (Dz.U. 2004, nr 210 poz. 2135, ze zmianami). 
Ustawa z dnia 27 października 2017 r. o podstawowej opiece zdrowotnej (Dz.U. 2017, poz. 2017, ze zmianami).

Ustawa z dnia 15 kwietnia 2011 r. o działalności leczniczej (Dz.U. 2011, nr 112 poz. 654 , ze zmianami).

Ustawa z dnia 21 listopada 1967 r. o powszechnym obowiązku obrony Rzeczypospolitej Polskiej (Dz.U. 1967, nr 44 poz. 220).

Ustawa z dnia 12 października 1990 r. o Straży Granicznej (Dz.U. 1990, nr 78 poz. 462 ,

ze zmianami).

Ustawa z dnia 6 czerwca 1997 r. - Kodeks karny wykonawczy (Dz.U. 1997, nr 90 poz. 557, ze zmianami).

Ustawa z dnia 27 lipca 2001 r. Prawo o ustroju sądów powszechnych (Dz.U. 2001, nr 98 poz. 1070, ze zmianami).

Ustawa z dnia 5 grudnia 2008 r. o zapobieganiu oraz zwalczaniu zakażeń i chorób zakaźnych u ludzi (Dz.U. 2008, nr 234 poz. 1570, ze zmianami).

Ustawa z dnia 9 czerwca $2011 \mathrm{r}$. o wspieraniu rodziny i systemie pieczy zastępczej (Dz.U. 2011, nr 149 poz. 887, ze zmianami).

Wyniki kontroli Najwyższej Izby Kontroli z dnia 27 października 2015 r.

Wyrok Sądu Najwyższego z dnia 13 maja 2005 r., sygn. akt I CK 691/04, LEX nr 603867.

Wyrok Sądu Najwyższego z dnia 22 stycznia 2014 r., sygn. akt III CSK 96/13, LEX nr 1455728.

Wyrok Wojewódzkiego Sądu Administracyjnego w Warszawie z dnia 22 stycznia 2010 r., sygn. akt VI SA/Wa 1387/09, LEX nr 600397.

Wyrok Wojewódzkiego Sądu Administracyjnego w Gdańsku, sygn. akt I SA/Gd 1038/17, LEX nr 2408710.

Wyrok Wojewódzkiego Sądu Administracyjnego w Łodzi, sygn. akt III SA/Łd 3/15, LEX nr 1793509.

Zimna T., Zawieranie umów o udzielanie świadczeń opieki zdrowotnej, LEX Wolters Kluwer, 2007.

\section{Kamil Musial: Primary care for children and youth}

\section{Summary}

The following article is an analysis of Polish legal acts concerning the organization of the primary health care, particularly the primary care for children and youth. 
The first chapter of the article presents the primary health care as a part of the Polish healtcare system. This article indicates that before the Polish parliament passed The Primary Health Care Act, this matter was regulated in several another legal acts, mostly in The Healthcare Benefits Act from 2004 year.

The next chapter focuses on the primary care for children and youth. The healthcare for children and youth was regulated in the international law and The Constitution of the Republic of Poland. Therefore, the primary care for children and youth is a very important matter in the Polish legal system, which is confirmed in regulations of legal acts.

The third chapter presents the main regulations in The Primary Health Care Act, particularly for children and youth. The passed act is a result of work of many lawyers and members of the medical environment.

To summarise, this article indicates the main reason to establish The Primary Health Care Act, and discusses its regulations. The most important issue for the healthcare for children and youth is creating procedures for a discussion about its regulations.

Keywords: primary health care, primary care physician, general practitioner, primary care nurse, primary care. 